\title{
Assessment of the Logistics Activities with A Structural Model on the Basis of Improvement of Sustainability Performance
}

Emel Yontar ( $\nabla$ eyontar@tarsus.edu.tr)

Tarsus University: Tarsus Universitesi https://orcid.org/0000-0001-7800-2960

\section{Research Article}

Keywords: Sustainable logistics, logistics sector, sustainability, logistics management, structural equation model

Posted Date: February 1st, 2022

DOl: https://doi.org/10.21203/rs.3.rs-1202383/v1

License: (1) (1) This work is licensed under a Creative Commons Attribution 4.0 International License. Read Full License 


\section{Abstract}

The rationale for prioritizing sustainability in our world, where climate change and unplanned population growth have increased noticeably and resources are exhausted, has affected almost every sector. The logistics sector, which is one of these sectors and undoubtedly directly affects the living resources, constitutes the subject of our study. The study deals with the logistics activities carried out by the companies on the basis of sustainability and the aim of the article is to provide a framework that will contribute to the sustainability initiative of the companies carrying out logistics activities. It provides gains to the literature by investigating the important factors that greatly affect the performance of logistics activities. Accordingly, logistics activities are detailed under the titles of environmental impact, waste management, transportation and warehouse management, resource usage, social impact, internal factors, external factors and logistics performance factors. These titles are the main dimensions that emerged as a result of literature research and expert opinions. The most important sub-criteria that affect the sustainable logistics performance, which are handled within the scope of the main dimensions, have been determined as 44 with Pareto analysis. These determined parameters are analyzed with the formation of a comprehensive structural model and their importance levels are interpreted, and the findings are interpreted. The results of this study, in which sustainable logistics practices are at the forefront, form the basis for improving the sustainability performance of the logistics sector.

\section{Introduction}

The increasing pressures with the social awareness that has developed in recent years, the concern caused by the rapid depletion of raw material resources, the increasing environmental problems for businesses on a global scale (Grant et al., 2017) and the emergence of the consequences of global warming emphasize the concept of sustainable logistics (Jørsfelt et al., 2016). The Brundtland Report on Sustainable Development, Our Common Future (WCED, 1987), which became popular after the 2005 United Nations Earth Summit, focuses on enhancing economic development, the contribution of social development to society, and improving environmental impacts. When evaluated from this perspective, the logistics sector not only makes a significant contribution to economic performance and development, but also shows that it has the potential to improve performance outputs with social gains by influencing environmental factors (Rashidi and Cullinane, 2019). These three factors (Economic-Social-Environmental) emphasized by sustainable development are called the Triple Bottom Line (TBL) (Elkington, 1997) and are at the focal point of the sectors.

From the perspective of sustainability in the logistics sector; Increasing globalization, outsourcing and trade relations, greater use of technology, lean and agile supply chain processes help logistics and supply chain management activities, while greenhouse gas emissions (Kowl, 2008) use of fuel and other natural resources, other types of pollution, Increasing waste types and packaging levels cause environmental, economic and social problems. In addition, about three to five percent of the total workforce is employed in this sector in most countries (Rashidi and Cullinane, 2019). Again, pollution, increased traffic, increasing concerns of greenhouse gases arising from the disposal and removal of hazardous materials, and the problem of not using the resources optimally have led to the emergence of a series of environmental laws. Environmental issues have become a growing concern for businesses on a global scale (Grant et al., 2017).

On the other hand, logistics activities can have many negative effects on societies that need to be minimized. For example, those that have adverse effects on people's health and safety; air, land, water, noise and visual pollution cause congestion, vibration, injuries and accidents (Abbasi and Nilsson, 2016). In this regard, the sustainable development of logistics requires activities that lead to the highest economic and social gains while reducing negative environmental losses. However, in the long run these activities are complex and subject to great difficulties and obstacles.

Since the logistics industry is clearly very important in achieving the sustainable development goals of a country, companies dealing with sustainable logistics in this study will be able to reach many parameters in order to minimize environmental pollution, provide social gain and gain competitive advantage. These parameters are the parameters that form the main lines of sustainable logistics; environmental impact, waste management, transportation and warehouse management, resource use, social impact, internal factors, external factors and logistics performance factors (Figure 1).

While all these parameters are provided, the information provided by the performance measurement in order to adopt the sustainability principle will enable the managers to make the right decisions about the implementation of sustainability performance in logistics and supply chains (Gunasekaran et al., 2004). Companies can evaluate the environmental impact, social analysis and contribution to profit by considering the parameters of sustainable logistics. At the same time, as seen in Figure 1, with the evaluation of all these parameters, it will be more possible to talk about sustainable logistics from A to Z throughout the company.

An application that helps countries identify the challenges, opportunities and what they can do to improve their logistics performance has been implemented and named as the Logistics Performance Index (LPI) (World Bank, 2017). In this study, LPI parameters were also included in the sustainable logistics criteria and associated with sustainability.

The purpose of this article is to provide a framework that will contribute to the sustainability initiative of companies operating in logistics. The main objectives of this study are as follows:

- To gain a perspective on the logistics industry by determining and evaluating parameters (dimensions). These dimensions are environmental impact, waste management, transportation and warehouse management, resource use, social impact, internal factors, external factors and logistics performance factors.

- To determine the degree of importance between the Structural Equation Model and the criteria by conducting a survey with the sub-criteria under these dimensions for the logistics sector.

- To detail and interpret the parameters that all chain employees in the logistics sector should pay attention to, from production to distribution, according to their weights. 
This article consists of five chapters and the other chapters are arranged as follows; In Chapter 2, studies related to sustainable logistics are researched and the criteria obtained in the literature study are summarized throughout the table, the place and importance of the study are emphasized. In Chapter 3 , the methodology of the study is given, along with the theoretical information, the model of the study is presented, data collection and data analysis are shown. In the next section (Chapter 4), the results of the modeled study are explained in detail and the findings are interpreted in detail. Finally, in Chapter 5 , the results are discussed, the data obtained are evaluated with previous studies and suggestions for future studies are presented.

\section{Literature Review}

In this section, both the theoretical aspect and the application points of the study are mentioned by keeping the studies on the basis of sustainable logistics in the foreground. At the same time, the author-criteria study is included to shed light on the study and to determine the criteria affecting sustainable logistics

(Table 1).

The literature of the logistics and supply chain disciplines shows the growing outlook for sustainable-based work. In terms of sustainable logistics and supply chain, it proceeds with the main goal of reducing environmental impact along the value chain from raw materials to final products, while also considering the profit contribution and society relationship. When logistics activity, which is one of the last links of supply chain management, is associated with sustainability, its importance has increased. Green and sustainable supply chain management is an interdisciplinary field that addresses both management and environmental sciences (Rajeev et al., 2017).

In this study, the concept of logistics, which is one of the most important activities of supply chain management, will be discussed and evaluated in terms of sustainability. There are many evaluations of supply chain management in terms of sustainability in the literature (Taticchi et al., (2013); Qorri et al., (2018); Kamble et al., (2020); Sharma et al., (2020); Subramanian et al.) al., (2020); Narimissa et al., (2019); Reddy et al., (2019); Bourlakis et al., (2014); Katiyar et al., (2017); Ramezankhani et al., (2018) ); Haghighi et al., (2016); Shibin et al., (2017); Chardine-Baumann and Botta-Genoulaz (2014); Kafa et al., (2013); Tseng et al., (2019)). These and similar studies have evaluated the sustainability performance by focusing mostly on supply chain management and have provided literature gains.

As an example of these studies; Kafa et al. (2013) focused on the concept of "Green" to emphasize the importance and need of sustainability performance and environmental issues in supply chain management. They developed key performance measures for green supply chain management that include concerns about sustainable development and proposed an analytical model. Chardine-Baumann and Botta-Genoulaz (2014), on the other hand, developed a model to evaluate the sustainable performance of a company's supply chain management practices. Haghighi et al. (2016) evaluated the sustainability performance of recycling companies with a new hybrid Data Envelopment Analysis-BSC framework, taking into account different economic, environmental and social indicators, in order to find the most efficient units at each level of supply chain networks. Ramezankhani et al. (2018), on the other hand, dynamically evaluated the performance of the supply chain to the automotive manufacturing sector in terms of both sustainability and flexibility over time. Krishnan et al. (2020) aimed to identify the current operational and resource deficiencies in the food supply chain and propose a framework for its redesign to improve environmental sustainability. Shibin et al. (2017) developed a theoretical framework to explain sustainable supply chain performance using the total interpretative structural modeling technique. Kamble et al., (2020) addressed specific criteria for practitioners to create a robust data-driven agri-food supply chain and achieve sustainable performance. According to Mardani et al. (2020) focused on literature studies of evaluating green and sustainable supply chain management using structural equation modeling.

If we look at the studies that deal with the concept of "Sustainable Logistics", which is a sub-branch of the sustainable supply chain management; According to Karaman et al. (2020) investigated the relationship between corporate governance, green logistics performance and sustainability reporting. Abbasi and Nilsson (2016) explored themes and challenges in developing environmentally sustainable logistics activities and identified customer priorities, administrative complexity, network instability, and technological and legal uncertainties as challenges. Lan and Zhong (2018) pointed out that the appropriate way to achieve the sustainable development of logistics and economy would be through coordinated development. Rashidi and Cullinane (2019) evaluated the sustainability of operational logistics performance across OECD countries and compared them with the Logistics Performance Index (LPI).

In addition to these studies, logistics studies in different fields in different sectors are handled with sustainability. In the electronics industry (Agrawal and Singh, 2019); in the paper industry (Neto et al., 2008); in freight logistics (Lee and Wu, 2014); sustainability evaluations in third-party logistics (Çetin and Sain; 2018), smart city logistics (Lan et al., 2020), and examining existing problems in terms of sustainability. In this study, which was prepared by considering different sectors, logistics activities were discussed in general terms and associated with sustainability. It is thought that this association will provide a framework for the literature by including the determination and detailed analysis of the parameters considered at the point of sustainable logistics. In addition to addressing different sectors in the literature, in addition to addressing different topics (carbon emission reduction, environmental impact analysis, sustainable development, logistics performance index, determination of difficulties and obstacles, etc.), determining the sustainable logistics criteria and investigating the impact levels is capable of closing.

With this study, it is aimed to reach the elements that are and should be the basis of sustainable logistics. For this purpose, studies compiled from the relevant literature are approached with a factor-oriented approach. Using the two main databases, Scopus and Web of Science (WoS) in the literature, a search is made with the keywords "sustainability" and "logistics", "sustainable logistics" and "green logistics" on the grounds that they are closely related. In the findings obtained, the fact that the desired study is studied with sustainability criteria is the most important reason for using it in this study. For this reason, in Table 1 as a result of the examinations; criteria and studies using these criteria are included. This analysis in Table 1 draws attention to which authors focus on which criteria. At the same time, the parameters used in the current study are included in the last column (16).

Table 1. Sustainable logistics parameters literature analysis 


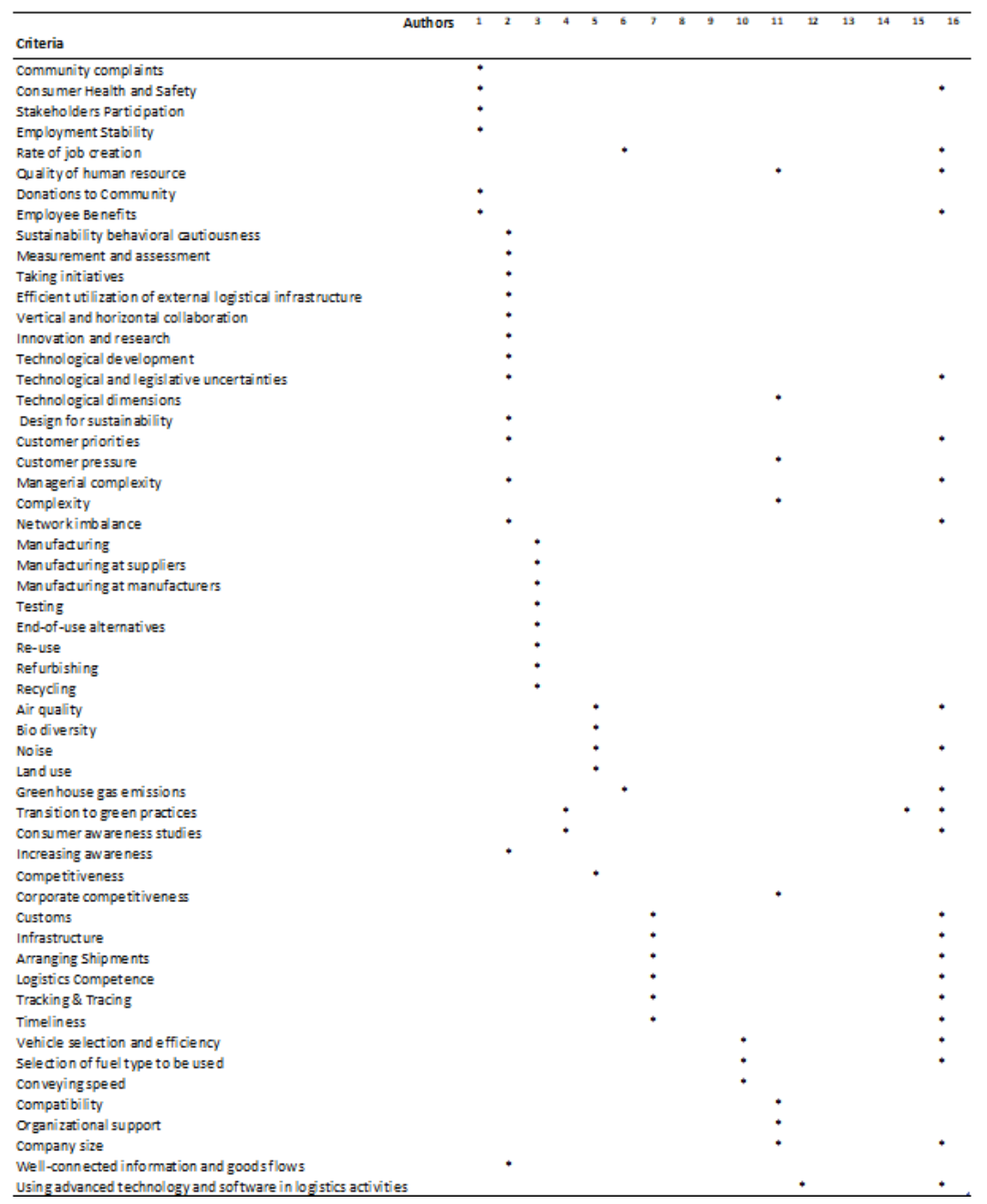

(1-Agrawal and Singh; 2019, 2-Abbasi and Nilsson, 2016; 3- Neto et al., 2008; 4-Beken, 2016; 5-Altuntaş and Türker, 2012; 6-Rashidi and Cullinane, 2019; 7-Arvis et al., 2010; 8-Zhang and Zhao 2012; 9-Krajewski, 2013; 10-Görgün and Bardakçı, 2020; 11-Lin and Ho, 2011; 12-Geiger, 2016; 13-Chunguang et al., 2008; 14Lai and Wong, 2012; 15-Pazirandeh and Jafari, 2013; 16-Author)

Looking at Table 1, it is seen that the authors working under the title of "sustainable logistics" and focusing on the factors in the literature. The criteria studied are taken with the net name used in each study and no changes are made on it. Thus, 105 criteria have been reached, and the first study of the determination of the "important" criteria targeted in this study is done with Pareto Analysis. Pareto Analysis is used in the literature because it focuses attention on the most important cause of the problem and helps to determine priorities. In this context, it was desired to reach the most important criteria out of 105 criteria. 5 experts working as senior managers in the logistics sector are asked to score between 1-10 on these criteri and the results are included in the chart (Figure 2).

As a result of the scoring, it is concluded that 39 criteria are more important and the study continued with these 39 criteria. At the same time, as a result of mutual discussion with the expert and the author of the study, 5 more criteria are added to the criteria table (Warehouse and stock management, climate change, women's employment and equal conditions, continuous training of employees, road safety). Then it was passed to the methodology part.

\section{Methodology}

This section includes the 39 criteria determined as a result of the Pareto Analysis and the 5 added criteria, which are considered as 44 criteria in total and analyzed with the help of the Structural Equation Model.

As an analytical method, the Structural Equation Model (SEM) can be explained as a reunion of factor analysis and multiple regression modeling (Davvetas et al., 2020). The factor analysis of the SEM model applicate to evaluating the suitability of the variables used in the model. SEM is a comprehensive statistical approach used to test models in which causal (indicated by one-way arrow) and correlational relationships between explicit (observed, measured) and latent (unobserved, unmeasured) variables coexist (Hoyle, 1995).

SEM offers the ability to predict more complex model structures that include variables operating simultaneously as the causes and consequences of other variables in the model. This allows estimation direct and indirect effects between a range of variables. SEM analysis represents testing all variables together and demonstrating the compatibility of findings with data. SEM, unlike other methods, examines both the dependent variables and independent variables under a single model. 
Unlike variables that can be measured directly, again, many parameters cannot be measured directly. These unobservable variables are called latent variables. One of the key benefits of structural equation model is that the relationships between latent and observed variables can be specified and measurement error is taken into account. Confirmatory factor analysis (CFA) is used to show how latent variables describe the observed variables. The purpose of CFA is to validate a model as a result of accessing hidden variables through observed variables (Kline, 2010).

When the studies on SEM in the literature are examined, it is seen that there is an effective evaluation of sustainability in the fresh fruit and vegetable (Yontar and Ersöz, 2020) or food sector (Yontar and Ersöz, 2021), and travel agencies benefit from SEM in investigating the factors that create brand values (Uygurtürk, 2014), while investigating the performance factors of accommodation facilities (Baldemir \& Bozkurt, 2012) and in researching validity and reliability (Çapık, 2014). Additionally; The inclusion of SEM in the six-sigma concept (Yemenici, 2012), the development of a model to improve the service quality (Díez-Mesa et al., 2018), the harmony of employees who want to serve in the health sector (Duff, 2019), the factors affecting the explosions.

(Kursunoğlu \& Önder, 2019) conducted research on the analysis. As can be seen, SEM represents a current and important method that is widely used in many different fields in the literature.

In this study, the effects of the sustainability theme, which brings together economic, environmental and social effects, on logistics are examined. The criteria required for sustainable logistics are determined as a result of a detailed scanning and analyzed in SEM and the interaction between each other is revealed. While determining the criteria, as a result of the detailed literature study (Table 1), the criteria determined based on sustainable logistics are included in Table 2. 
Table 2

Criteria used in the study

\begin{tabular}{|c|c|c|c|}
\hline Measurement variable & Authors & $\begin{array}{l}\text { LISREL } \\
\text { Code }\end{array}$ & Latent variable \\
\hline Air quality & Altuntaş and Türker, 2012 & L1 & \multirow[t]{6}{*}{ Environmental Factors } \\
\hline Noise pollution & Altuntaş and Türker, 2012 & L2 & \\
\hline Climate change & Author & L3 & \\
\hline Greenhouse gas emissions (GHGE) & Rashidi and Cullinane, 2019 & L4 & \\
\hline Energy use & Rashidi and Cullinane, 2019 & L5 & \\
\hline Transition to green practices & $\begin{array}{l}\text { Beken, 2016; Pazirandeh and Jafari, } \\
2013\end{array}$ & L6 & \\
\hline Waste management & Altuntaş and Türker, 2012 & L7 & \multirow[t]{5}{*}{ Waste Management } \\
\hline Recycle efficiency & Agrawal and Singh, 2019 & L8 & \\
\hline Quantity of returned products & Agrawal and Singh, 2019 & L9 & \\
\hline Use of recycled material & Agrawal and Singh, 2019 & L10 & \\
\hline Reverse logistics applications & Krajewski, 2013 & L11 & \\
\hline Production and distribution planning & Görgün and Bardakçı, 2014 & L12 & \multirow{5}{*}{$\begin{array}{l}\text { Transport and Warehouse } \\
\text { Management }\end{array}$} \\
\hline Transport optimization & Agrawal and Singh, 2019 & L13 & \\
\hline Choice of mode of transport and intermodal transport & Görgün and Bardakçı, 2014 & L14 & \\
\hline Warehouse and stock management & Author & L15 & \\
\hline Network imbalance & Abbasi and Nilsson, 2016 & L16 & \\
\hline $\begin{array}{l}\text { Internal resources efficiency, effectiveness, and } \\
\text { utilization }\end{array}$ & Abbasi and Nilsson, 2016 & L17 & \multirow[t]{5}{*}{ Resource Usage } \\
\hline Energy and fuel efficiency & Abbasi and Nilsson, 2016 & L18 & \\
\hline Reduced packaging & Agrawal and Singh, 2019 & L19 & \\
\hline Vehicle selection and efficiency & Görgün and Bardakçı, 2014 & L20 & \\
\hline Selection of fuel type to be used & Görgün and Bardakçı, 2014 & L21 & \\
\hline Consumer health and safety & Agrawal and Singh, 2019 & L22 & \multirow[t]{8}{*}{ Social Factors } \\
\hline Rate of job creation & Rashidi and Cullinane, 2019 & L23 & \\
\hline Quality of human resource & Lin and Ho, 2011 & L24 & \\
\hline Employee benefits & Agrawal and Singh, 2019 & L25 & \\
\hline Women's employment and equal conditions & Author & L26 & \\
\hline Continuous training of employees & Author & L27 & \\
\hline Consumer behavior & Agrawal and Singh, 2019 & L28 & \\
\hline Consumer awareness studies & Beken, 2016 & L29 & \\
\hline Logistics cost optimization & Agrawal and Singh, 2019 & L30 & \multirow[t]{5}{*}{ Internal Factors } \\
\hline Company size & Lin and Ho, 2011 & L31 & \\
\hline Managerial complexity & Abbasi and Nilsson, 2016 & L32 & \\
\hline $\begin{array}{l}\text { Using advanced technology and software in logistics } \\
\text { activities }\end{array}$ & Geiger, 2016 & L33 & \\
\hline Supply chain integration & Agrawal and Singh, 2019 & L34 & \\
\hline \multirow[t]{2}{*}{ Government support / Government regulated laws } & $\begin{array}{l}\text { Agrawal and Singh, 2019, Lin and Ho, } \\
\text { 2011, }\end{array}$ & L35 & \multirow[t]{4}{*}{ External Factors } \\
\hline & $\begin{array}{l}\text { Chunguang et al., 2008, Lai and Wong, } \\
2012\end{array}$ & & \\
\hline Technological and legislative uncertainties & Abbasi and Nilsson, 2016 & L36 & \\
\hline Customer priorities & Abbasi and Nilsson, 2016 & L37 & \\
\hline
\end{tabular}




\begin{tabular}{|c|c|c|c|}
\hline Measurement variable & Authors & $\begin{array}{l}\text { LISREL } \\
\text { Code }\end{array}$ & Latent variable \\
\hline Road safety & Author & L38 & \\
\hline Customs & Arvis et al., 2010 & L39 & \multirow[t]{6}{*}{ Logistics Performance Factor } \\
\hline Tracking \& Tracing & Arvis et al., 2010 & L40 & \\
\hline Timeliness & Arvis et al., 2010 & L41 & \\
\hline Logistics competence & Arvis et al., 2010 & L42 & \\
\hline Infrastructure & Arvis et al., 2010 & L43 & \\
\hline Arranging shipments & Arvis et al., 2010 & L44 & \\
\hline
\end{tabular}

The 44 criteria determined as a result of Table 1 are grouped under eight main dimensions in Table 2. These dimensions are; environmental factors, waste management, transportation and warehouse management, resource use, social factors, internal factors, external factors, logistics performance factors. Among the 44 criteria determined (Table 2); warehouse and stock management, women's employment and equal conditions, continuous training of employees, road safety are unique criteria that are thought to be important to be addressed in sustainable logistics, which are included in this study independent of the literature. Thus, measurement variables (44 criteria) and latent variables (8 dimensions) for sustainable logistics are included in the study.

\subsection{Data collecting}

For sustainable logistics, data collection studies begin with the determination of latent and measurement variables. Data collection includes sample selection, creation of surveys, and administration of surveys. A sample to represent this group is selected from the entire group (the universe) that is relevant to the research. Collecting information from a selected sample from the population rather than the entire population is a cheaper, faster and easier way (De Vaus, 1990). Since the group that our study is interested in is the logistics sector, first of all, logistics companies are taken into account for sample selection. Then, the opinions of the academicians working in this field in the academy are sought. In order to ensure validity, an acceptable sample size is obtained by taking the opinions of 392 people at the $95 \%$ confidence interval.

After the sample selection studies, the survey form preparation process comes. By giving importance to the criteria of preparing the questionnaire, dimensions or parameters in the questionnaire form; used as latent variables and criteria as measurement variables. In the evaluation of the criteria, the respondent is asked to evaluate the criteria according to the degree of importance with a 5-point Likert Scale. The questionnaire forms prepared online by Google forms are sent to the logistics sector employees in the relevant field (companies with middle and senior managers and their own logistics units were preferred), 508 questionnaires are sent to the group of academicians working in logistics and supply chain management at universities, and these questionnaires are asked to be answered. The response rate is around $77.62 \%$ and 392 survey results are obtained. The demographic characteristics of the questionnaire applied to 392 academicians working in the logistics line are given in Table 3.

Table 3.Demographic features

\begin{tabular}{cccccccccc|cccc}
\hline \multicolumn{1}{c|}{ Gender } & \multicolumn{4}{c}{ Age range } & \multicolumn{2}{c}{ Workplace } & \multicolumn{3}{c}{ Years of experience } \\
\hline Man & Woman & $20-30$ & $31-40$ & $41-50$ & $51-60$ & $60+$ & Logistics & University & $0-5$ & $6-10$ & $11-15$ & $16-20$ & $20+$ \\
\hline 207 & 185 & 136 & 102 & 108 & 24 & 22 & 221 & 171 & 118 & 58 & 54 & 64 & 98 \\
\hline
\end{tabular}

According to this, while 221 people out of 392 people are experienced in the logistics sector, 171 people formed the academic group. The years of experience of the group consisting of middle and senior managers of the logistics sector are also noteworthy; While 98 people have 20 or more years of industry experience, 118 people have 10 years or more working time. The study is generally applied in Turkey and the results are obtained consistently.

\subsection{Analysis of data}

In this section, reliability analysis of all factors determined in the study is performed. Cronbach's alpha (a) statistics are used to determine the internal consistency of the factors within the framework of reliability analysis. Cronbach alpha statistics take the value in the range 0 - 1 . In Cronbach's alpha statistics, reliability coefficients of about 0.90 are generally accepted as "excellent", values of 0.80 as "very good" and values of about 0.70 as "sufficient" (Kline, 2010 ).

Table 4 shows the reliability values obtained for the factors. When Table 4 is examined, the reliability values obtained for all dimensions and the entire criterion are found to be above 0.70 . As a result of the calculations, the environmental factors dimension is 0.900 with 6 variables, the waste management dimension is 0.899 with 5 variables, the transport and warehouse management dimension is 0.839 with 5 variables, the resource usage dimension is 0.801 with 5 variables, the social factors dimension is 0.872 with 8 variables, internal factors dimension is 0.828 with 5 variables, external factors dimension is 0.760 with 4 variables, logistics performance factors dimension is 0.836 with 6 varibales.

The general reliability coefficient, which includes all 44 variables, is determined as 0.942 , which indicates the very high reliability of the research scale. 
Reliability values for the sustainability logistics criteria.

\begin{tabular}{|ll|}
\hline Factor & Reliability Value (Cronbach's Alpha - a) \\
\hline Environmental Factors (6 variables) & 0,900 \\
\hline Waste Management (5 variables) & 0,899 \\
\hline Transport and Warehouse Management (5 variables) & 0,839 \\
\hline Resource Usage (5 variables) & 0,801 \\
\hline Social Factors (8 variabales) & 0,872 \\
\hline Internal Factors (5 variables) & 0,828 \\
\hline External Factors (4 variables) & 0,760 \\
\hline Logistıcs Performance Factors (6 varibales) & 0,836 \\
\hline General Reliability Coefficient (44 variables) & 0,942 \\
\hline
\end{tabular}

As a result of the high reliability coefficient determined after the reliability study, modeling studies are started in SEM.

\section{Results}

SEM consists of two parts as the measurement model and the structural model. Measurement variables that will take place under the dimensions as well as demographic characteristics are tested with the help of the measurement model. The measurement model is found in LISREL by applying SIMPLIS codes. After assigning measurement variables (dimensions) to latent variables (criteria), Confirmatory Factor Analysis is performed, as shown in Figure 3 . The results obtained according to the CFA results of the designed model show the compatibility of the questions in the model with the dimensions. The fact that the numbers in the arrows from the dimensions to the questions are close to 1 is shown under the name of standard solution, where the degree of compatibility of the questions with the dimensions is high.

Model fit captures the extent to which the data used to predict the model resembles the form the data should have if the hypothesized model is actually true (Davvetas et al., 2020). The greater the similarity or fit, the better the overall fit of the model. First of all, the test of this fit is provided with a Chi-square statistic (Davvetas et al., 2020). In addition, over the years, a long list of additional fit indices (RMSEA, NFI, SRMR etc.) has been in the literature, with suggested to evaluate the acceptability of the model.

The fit indices of the model, which are determined to be statistically significant according to the standardized estimation results calculated from the fit statistic evaluations in the CFA model (Table 5). According to Table 5, Chi-square/DF value of 2.98 indicates a good fit, and a RMSEA value of 0.071 indicates an acceptable fit. With the acceptance of the model as a result of these fit indices, the second stage of SEM, the structural model study, is started.

Table 5. List of fit statistics of measurement model result

\begin{tabular}{ccccc}
\hline $\begin{array}{c}\text { Goodness of fit } \\
\text { statistics }\end{array}$ & Good fit & Acceptable fit & Results & Evaluation \\
\hline RMSEA & $0<\mathrm{RMSEA}<0.05$ & $0.05<\mathrm{RMSEA}<0.10$ & 0.071 & Acceptable fit \\
$\mathrm{NFI}$ & $0.95 \leq \mathrm{NFI} \leq 1$ & $0.90 \leq \mathrm{NFI} \leq 0.95$ & 0.92 & Acceptable fit \\
$\mathrm{CFI}$ & $0.97 \leq \mathrm{CFI} \leq 1$ & $0.95 \leq \mathrm{CFI} \leq 0.97$ & 0.95 & Acceptable fit \\
$\mathrm{IFI}$ & $0.95 \leq \mathrm{FI} \leq 1$ & $0.90 \leq \mathrm{IFI} \leq 0.95$ & 0.95 & Good fit \\
SRMR & $0 \leq \mathrm{SRMR} \leq 0.05$ & $0.05 \leq \mathrm{SRMR} \leq 0.10$ & 0.068 & Acceptable fit \\
$\mathrm{DF}$ & & & 871 & \\
$\mathrm{NTWLS} \mathrm{Ki-kare}$ & At least & At least & $2598.95(\mathrm{P}=0.0)$ & \\
Ki-kare/DF & $<3$ & $<5$ & 2.98 & Good fit \\
\hline
\end{tabular}

The structural model showing the hidden variables and measurement variables in the model is also shown in Figure 4. By examining both dependent variables and independent variables under a single model, the main criterion and the relations of the variables with each other were analyzed. According to Figure 4, dependent variables are variables that are affected by other dimensions, while independent variables are variables that are not affected by other dimensions. Here, while waste management, transport and warehouse management, external factors, logistics performance factors are the independent variables; Environmental factors, resource usage, social factors and internal factors were determined as dependent variables.

Expansion of the notations defined according to Figure 4 is given in Table 6. Accordingly, the regression coefficients $(\lambda)$ seen in the model show the degree of influence of the variables on each other. If these values are " $<0.10$, low effect; If it is around 0.30 , the effect is at a normal level; $>0.50$ indicates the degree of "high impact" (Kline, 2011). 
Table 6

Explanation of notations for sample SEM

notation (Davvetas et al., 2020)

\begin{tabular}{|ll|}
\hline Notation & Term \\
\hline$\zeta$ & Exogenous latent variable \\
\hline$\eta$ & Endogenous latent variable \\
\hline$y$ & Exogenous variable indicator \\
\hline$\zeta$ & Endogenous variable indicator \\
\hline$\delta$ & Manifest variable error \\
\hline$\varepsilon$ & Manifest variable error \\
\hline$\lambda$ & Indicator loading \\
\hline$Y$ & Causal relationship \\
\hline$\beta$ & Causal relationship \\
\hline$\phi$ & Non-directional relationship \\
\hline
\end{tabular}

It is seen in detail in Figure 4 that the effect levels of sustainable logistics criteria between each other are very important. The arrow signs (i.e., the degree of influence $(\lambda)$ ) from each dimension to the sub-criterion they belong to, take a value between 0.47 and 0.85 , explaining this.

The independent variables of waste management, transport and warehouse management, external factors, logistics performance factors; The regression coefficients for the dependent variables of environmental factors, resource usage, social factors and internal factors also have effect levels between 0.20 and 0.72 .

Waste management; while it affects environmental factors by 0.44 , it affects resource use by 0.53 . In this context, environmental regulations and optimum resource use will change in direct proportion with a comprehensive waste management study. By increasing recycling efficiency, improving the quality of returned products, increasing the use of returned materials, and studies on reverse logistics applications, resource use and environmental factors will provide significant improvement.

Transport and warehouse management; It has a significant effect on resource usage at a rate of 0.47 . Existing resources will be more sustainable with effective transport and warehouse management efforts. If the production and distribution planning studies, Warehouse and stock management are done consciously and controlled, distribution optimization is ensured, network imbalance is prevented by providing Choice of mode of transport and intermodal transport, resource usage will be at an optimum level within these parameters.

External factors; It affects the social factors with a high regression coefficient of 0.72 . Social factors will increase further with increasing sustainable logistics efforts with government support, reduced technological and legal uncertainties, customer priorities and road safety.

Logistics Performance Index (LPI); affects internal factors with a normal effect level of 0.37. Composed of Customs, Tracking \& Tracing, Timeliness, Logistics competence, Infrastructure, Arranging shipments factors, LPI is an interactive benchmarking tool created to help countries identify the challenges and opportunities they face in their trade logistics performance, and what they can do to improve their performance. With this comparison, the studies carried out by the logistics companies, which we define as internal factors, cost optimization, supply chain integration, and the logistics software they use will have a positive effect on the companies.

In addition to these, according to the model; environmental factors from $0.40 \%$ resource use; social factors are affected by 0.20 percent of resource use and internal factors are affected by 0.33 percent of resource use. In other words, among the criteria under the resource usage dimension; By ensuring the efficiency, effectiveness and use of internal resources at the optimum level, reducing the use of packaging, which is one of the most important logistics activities, or applying environmentally-based green packaging, ensuring energy and fuel efficiency, vehicle selection and fuel type, both environmental and social factors and internal factors will be positively affected. While the environmental factors were more affected by resource use (0.40), the lowest impact was on social factors (0.20).

\section{Conclusion}

In our world where global climate changes are experienced and sustainability is prioritized, sustainable logistics practices are on the world agenda as a logistics management strategy that can be extremely effective. Environmental, economic and social factors that should be considered while addressing sustainability form the main framework of TBL and are associated with the logistics sector in this study.

The first step for the method is the structural equation modeling study. While waste management, transportation and warehouse management, external factors, logistics performance factors are the independent variables; environmental factors, resource use, social factors and internal factors were determined as dependent variables. Independent variables are those that are not affected by other parameters; dependent variables are those that are affected by other parameters. In this case, waste management, transportation and warehouse management, external factors, logistics performance factors; They affect environmental factors, resource use, social factors and internal factors. The effects of the sub-criteria under this dimension are also examined. Use of recycled 
material $(\lambda=0.85)$, warehouse and stock management $(\lambda=0.77)$, road safety $(\lambda=0.73)$, customs and tracking \& tracing $(\lambda=0.77)$, noise pollution $(\lambda=0.84)$, vehicle selection and Efficiency $(\lambda=0.73)$, employee benefits $(\lambda=0.83)$, supply chain integration $(\lambda=0.85)$ measurement variables are the factors that affect the dimensions they are connected to the most. The sub-criteria under each dimension and affecting it with the highest degree of impact show that these criteria determined in the study are very important.

With this study, the output of the following items is given in the study:

- The study deals with logistics operations on the basis of sustainability.

- It explores the important factors that greatly affect the performance of logistics activities. These determined factors will help administrators and academics in making decisions.

- The study relates the logistical trend of sustainability and adds to the few studies available.

- Since the study emphasizes the importance of sustainability, it allows for sectoral and therefore country-wide development if arrangements are made according to the determined parameters.

- The results provide the basis for improving the sustainability performance of the logistics industry.

In terms of suggestions for future studies on the overall study, first of all, the obtained parameters and criteria and the importance of different methods (DEMATEL etc.) can be determined and compared with the findings here. At the same time, with the use of criteria, a logistics-sustainable performance evaluation (Mathematical models, Multiple Criteria Decision Making Methods, etc.) study can be applied by considering certain companies. Studies can be extended to the literature by multiplying.

\section{Declarations}

Data Availability: Availability of data, he data that support the findings of this study are available from the corresponding author, [E.Y.], upon reasonable request. Also, available at this linkhttps://data.4tu.nl/account/articles/16601099

Authors Contributions: EY; conceptualization, methodology, investigation, analysis and writing.

Ethical approval and consent to participate: Not applicable.

Consent to Publish: Not applicable.

Funding: Not applicable.

Competing interests: The author declare no competing interests.

\section{References}

1. Abbasi, M., \&Nilsson, F. (2016). Developingenvironmentallysustainablelogistics: Exploringthemesandchallengesfrom a logistics service providers' perspective. TransportationResearchPart D: Transport and Environment, 46, 273-283.

2. Abukhader, S. M., \&Jönson, G. (2004). Logisticsandtheenvironment: Is it an establishedsubject?. International Journal of LogisticsResearchand Applications, 7(2), 137-149.

3. Agrawal, S., \& Singh, R. K. (2019). Analyzingdispositiondecisionsforsustainablereverselogistics: TripleBottomLineapproach. Resources, ConservationandRecycling, 150, 104448.

4. AIM Global. (2008). AIM Global PredictsIncreasedAcceptance, Utilization Of RFID Technologies in Green Applications of RFID Technologies in Green Applications, http://www.aimglobal.org/members/news/templates/template.aspx?articleid=3240\&zoneid=1.

5. Altuntaş, C., \& Türker, D. (2012). Sustainablesupplychains: A contentanalysis of sustainabilityreports. DokuzEylülÜniversitesiSosyalBilimlerEnstitüsüDergisi, 14 (3), 39-64.

6. Arvis, J. F., AlinaMustra, M., Ojala, L., Shepherd, B., \&Saslavsky, D. (2010). ConnectingtoCompete 2010: TradeLogistics in the Global EconomyTheLogisticsPerformance Index andltsIndicators. World Bank.

7. Baldemir, E., \& Bozkurt, B. (2013). Konaklama Tesislerinin Performanslarını Etkileyen Faktörlerin İncelenmesi: Marmaris Örneği. Muğla Üniversitesi Sosyal Bilimler Enstitüsü Dergisi, (29), 27-43.

8. Beken, H. G. (2016). Sürdürülebilirlikverekabetedebilirlikyoluyeşillojistik mi. Balkan ve Yakın Doğu Sosyal Bilimler Dergisi, 2(01), 78-88.

9. Bourlakis, M., Maglaras, G., Aktas, E., Gallear, D., \&Fotopoulos, C., Firm size andsustainableperformance in foodsupplychains: InsightsfromGreekSMEs. International Journal of ProductionEconomics, 152, 112-130, 2014.

10. Chardine-Baumann, E., \& Botta-Genoulaz, V., A frameworkforsustainableperformanceassessment of supplychainmanagementpractices. Computers\&IndustrialEngineering, 76, 138-147, 2014.

11. Chunguang, Q., Xiaojuan, C., Kexi, W., \&Pan, P. (2008, December). Research on greenlogisticsandsustainabledevelopment. In 2008 International Conference on Information Management, Innovation Management andlndustrialEngineering (Vol. 3, pp. 162-165). IEEE.

12. Commission for Integrated Transport (2007) Transport and Climate Change: Advice to government from the commission for integrated transport, Commission for Integrated Transport, London.

13. Çapık, C. Geçerlik Ve Güvenirlik Çalışmalarında Doğrulayıcı Faktör Analizinin Kullanımı. Anadolu Hemşirelik ve Sağlık Bilimleri Dergisi, 17(3). 
14. Çetin, Ö. Ü. O., \&Sain, A. D. (2018). Lojistik sektöründe sürdürülebilirlik uygulamaları.

15. David B, G., Trautrims, A., \& Wong, C. Y. (2021). Sustainable logistics and supply chain management.

16. Davvetas, V., Diamantopoulos, A., Zaefarian, G., \&Sichtmann, C. (2020). Ten basicquestionsaboutstructuralequationsmodelingyoushouldknowtheanswersto-But perhapsyoudon't. Industrial Marketing Management, 90, $252-263$.

17. De Vaus, D.A., (1990) Surveys in SocialResearch (ContemporarySocialResearch S.), 2. Basım, UnwinHyman, London.

18. Díez-Mesa, F., de Oña, R., \& de Oña, J. (2018). Bayesiannetworksandstructuralequationmodellingtodevelop service qualitymodels: Metro of Sevillecasestudy. TransportationResearchPart A: PolicyandPractice, 118, 1-13.

19. Duff, E. (2019). A structuralequation model of empowermentfactorsaffectingnursepractitionerscompetence. Nurseeducation in practice, $38,145-152$.

20. Elkington, J. (1994). Towardsthesustainablecorporation: Win-win-winbusinessstrategiesforsustainabledevelopment. California managementreview, 36(2), 90-100.

21. Elkington, J. (1997). Thetriplebottomline. Environmentalmanagement: Readingsandcases, 2.

22. Geiger, C. (2016). ICT in greenfreightlogistics. InGreentransportationlogistics (pp. 205-241). Springer, Cham.

23. Görgün ve Bardakçı, (2020) GreenLogıstıcsAndApplıcatıons Of GreenLogıstıcsInTurkey Yeşil Lojistik Ve Türkiye'de Yeşil Lojistik Uygulamaları, 4th Internatıonal Zeugma Conference On ScientıfıcResearches.

24. Grant, D. B., Wong, C. Y., \&Trautrims, A. (2017). Sustainablelogisticsandsupplychainmanagement: principlesandpracticesforsustainableoperationsandmanagement. KoganPagePublishers.

25. Gunasekaran, A., Patel, C., \&McGaughey, R. E. (2004). A frameworkforsupplychainperformancemeasurement. International journal of productioneconomics, $87(3), 333-347$.

26. Haghighi, S. Motevali, S. A. Torabi, and R. Ghasemi. An integratedapproachforperformanceevaluation in sustainablesupplychainnetworks (with a casestudy). Journal of cleanerproduction 137: 579-597, 2016.

27. Hoyle, R. H. (1995). Structuralequationmodeling: Concepts, issues, andapplications. Sage.

28. Jørsfeldt, L. M., Hvolby, H. H., Nguyen, V. T., (2016). “Implementingenvironmentalsustainability in logisticsoperations: a casestudy” Strategic Outsourcing: An International Journal, 9(2), s. 98-125.

29. Kafa, Nadine; Hani, Yasmina; El Mhamed, Abederrahman. Sustainabilityperformancemeasurementforgreensupplychainmanagement. IFAC ProceedingsVolumes, 46.24: 71-78, 2013.

30. Kamble, S. S., Gunasekaran, A., \&Gawankar, S. A. Achievingsustainableperformance in a data-drivenagriculturesupplychain: A reviewforresearchandapplications. International Journal of ProductionEconomics, 219, 179-194, 2020.

31. Karaman, A. S., Kilic, M., \& Uyar, A. (2020). Greenlogisticsperformanceandsustainabilityreportingpractices of thelogisticssector: Themoderatingeffect of corporategovernance. Journal of CleanerProduction, 258, 120718.

32. Katiyar, R., Meena, P. L., Barua, M. K., Tibrewala, R., \& Kumar, G., Impact of sustainabilityandmanufacturingpractices on supplychainperformance: Findingsfrom an emergingeconomy. International Journal of ProductionEconomics, 197, 303-316, 2018.

33. Kline, R. B. (2010). Promiseandpitfalls of structuralequationmodeling in giftedresearch.

34. Kline, R.B. (2011). Principles and practice of structural equation modeling. New York: The Guilford Press.

35. Kowl, Andy. (2008). Global Environmental Benefits from RFID. RFID Switchboard. Issue, \#164, http://www.rfidsb.com/rfid-street-your-weekly-inside-scooprfid/444-global-environmentalbenefits-rfid.html.

36. Krajewski, L. J., Ritzman, L. P., \& Malhotra, M. K. (2013). Operations management: processesandsupplychains (Vol. 1). New York, NY: Pearson.

37. Krishnan, R., Agarwal, R., Bajada, C., \&Arshinder, K. Redesigning a foodsupplychainforenvironmentalsustainability-An analysis of resourceuseandrecovery. Journal of CleanerProduction, 242, 118374, 2020.

38. Kursunoglu, N., \&Onder, M. (2019). Application of structuralequationmodelingtoevaluatecoalandgasoutbursts. Tunnellingand Underground Space Technology, 88, 63-72.

39. Lai, K. H., \&Wong, C. W. (2012). Greenlogisticsmanagementandperformance: SomeempiricalevidencefromChinesemanufacturingexporters. Omega, 40(3), 267-282.

40. Lan, S. L., \&Zhong, R. Y. (2018). Coordinateddevelopmentbetweenmetropolitaneconomyandlogisticsforsustainability. Resources, ConservationandRecycling, 128, 345-354.

41. Lan, S., Tseng, M. L., Yang, C., \&Huisingh, D. (2020). Trends in sustainablelogistics in majorcities in China. Science of The Total Environment, $712,136381$.

42. Lee, K. H., \&Wu, Y. (2014). Integratingsustainabilityperformancemeasurementintologisticsandsupplynetworks: A multi-methodologicalapproach. The British Accounting Review, 46(4), 361-378.

43. Lin, C. Y., \&Ho, Y. H. (2011). Determinants of greenpracticeadoptionforlogisticscompanies in China. Journal of businessethics, 98(1), 67-83.

44. Mayfield, 2021. https://www.blog.shippypro.com/sustainable-

logistics/\#: :text=Sustainable\%20logistics\%20maintains\%20the\%20overarching,impact\%20of\%20all\%20logistical\%20activities.\&text=Sustainability\%20I

45. McKinnon, A, Browne, M and Whiteing, A (2012) Green Logistics: Improving the environmental sustainability of logistics, 2nd edn, Kogan Page, London

46. Narasimhan, Ram, JayaramJayanth, CausalLinkagesInSupplyChain Management: An Explora-toryStudy of North AmericanManufacturingFirms", DecisionSciences, Volume 29, Num-ber 3, Summer, 1998.

47. Neto, J. Q. F., Bloemhof-Ruwaard, J. M., vanNunen, J. A., \&vanHeck, E. (2008). Designingandevaluatingsustainablelogisticsnetworks. International journal of productioneconomics, 111(2), 195-208. 
48. Pazirandeh, A., \&Jafari, H. (2013). Making sense of greenlogistics. International Journal of Productivity andPerformance Management.

49. Qorri, Ardian, ZlatanMujkić, andAndrzejKraslawski. A conceptualframeworkformeasuringsustainabilityperformance of supplychains. Journal of CleanerProduction 189: 570-584, 2018.

50. Rajeev, A., Pati, R. K., Padhi, S. S., \&Govindan, K. (2017). Evolution of sustainability in supplychainmanagement: A literaturereview. Journal of CleanerProduction, 162, 299-314.

51. Ramezankhani M.J., Torabi S. A., Vahidi F., Supplychainperformancemeasurementandevalua-tion: A mixedsustainabilityandresilienceapproach, Computers\&IndustrialEngineering 126, 531-548, 2018.

52. Rashidi, K., \&Cullinane, K. (2019). Evaluatingthesustainability of nationallogisticsperformanceusing Data Envelopment Analysis. Transport Policy, 74, 3546.

53. ReddyKa, JaganMohan, andNeelakanteswaraRao Ab. "A review on supplychainperformancemeasurementsystems." ProcediaManufacturing 30: 40-47, 2019.

54. Sharma, R., Kamble, S. S., Gunasekaran, A., Kumar, V., \& Kumar, A. A systematicliteraturereview on machinelearningapplicationsforsustainableagriculturesupplychainperformance. Computers\& Operations Research, $104926,2020$.

55. Shibin, K. T., AngappaGunasekaran, andRameshwarDubey. Explainingsustainablesupplychainperformanceusing a total interpretivestructuralmodelingapproach. SustainableProductionandConsumption 12: 104-118, 2017

56. Taticchi, Paolo, FlavioTonelli, andRobertoPasqualino. Performancemeasurement of sustainablesupplychains: A literaturereviewand a researchagenda. International Journal of Productivity andPerformance Management 62.8: 782- 804, 2013.

57. Tseng, Ming-Lang, et al. "A literaturereview on greensupplychainmanagement: Trendsandfuturechallenges." Resources, ConservationandRecycling 141: 145-162, 2019.

58. Uygurtürk, H. (2014). Marka Değerini Oluşturan Faktörlerin Yapısal Eşitlik Modeli ile Analizi: Seyahat Acentaları Üzerine Bir Araştırma (Doctoraldissertation, Doktora Tezi, Bülent Ecevit Üniversitesi, Sosyal Bilimler Enstitüsü, Zonguldak).

59. WCED, S. W. S. (1987). World commission on environmentanddevelopment. Ourcommonfuture, 17(1), 1-91.

60. World Bank (2017), International LPI Global Ranking. https://lpi.worldbank.org/international/global World Bank. Retrieved 13 November 2017.

61. World Economic Forum (2009) Supply Chain Decarbonization: The role of logistics and transport in reducing supply chain carbon emissions, World Economic Forum, Geneva

62. Yemenici, N. K. (2012). Altı sigma metodolojisinde yapısal eşitlik modelinin araç olarak kullanılması.

63. Yontar, E., \& Ersöz, S. (2020). Investigation of FoodSupplyChainSustainabilityPerformanceforTurkey'sFoodSector. Frontiers in SustainableFoodSystems, 4, 68.

64. Yontar, E., \& Ersöz, S. (2021). Sustainabilityassessmentwithstructuralequationmodeling in freshfoodsupplychainmanagement. EnvironmentalScienceandPollutionResearch, 1-18.

65. Zhang, G., \&Zhao, Z. (2012). Greenpackagingmanagement of logisticsenterprises. PhysicsProcedia, 24, 900-905.

\section{Figures}

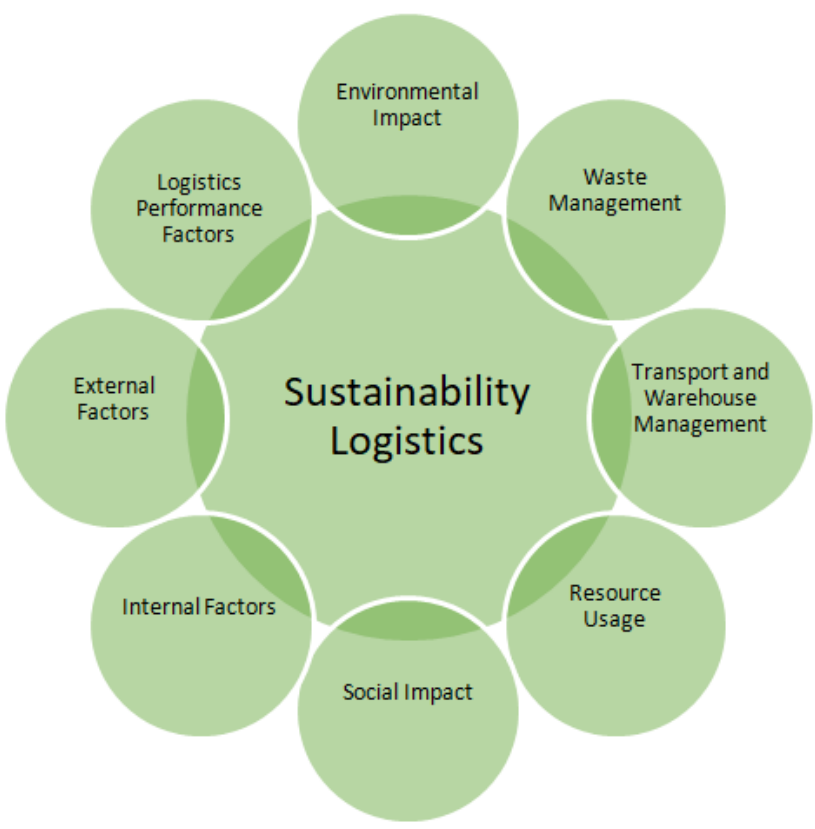

Figure 1

Sustainable logistics parameters 


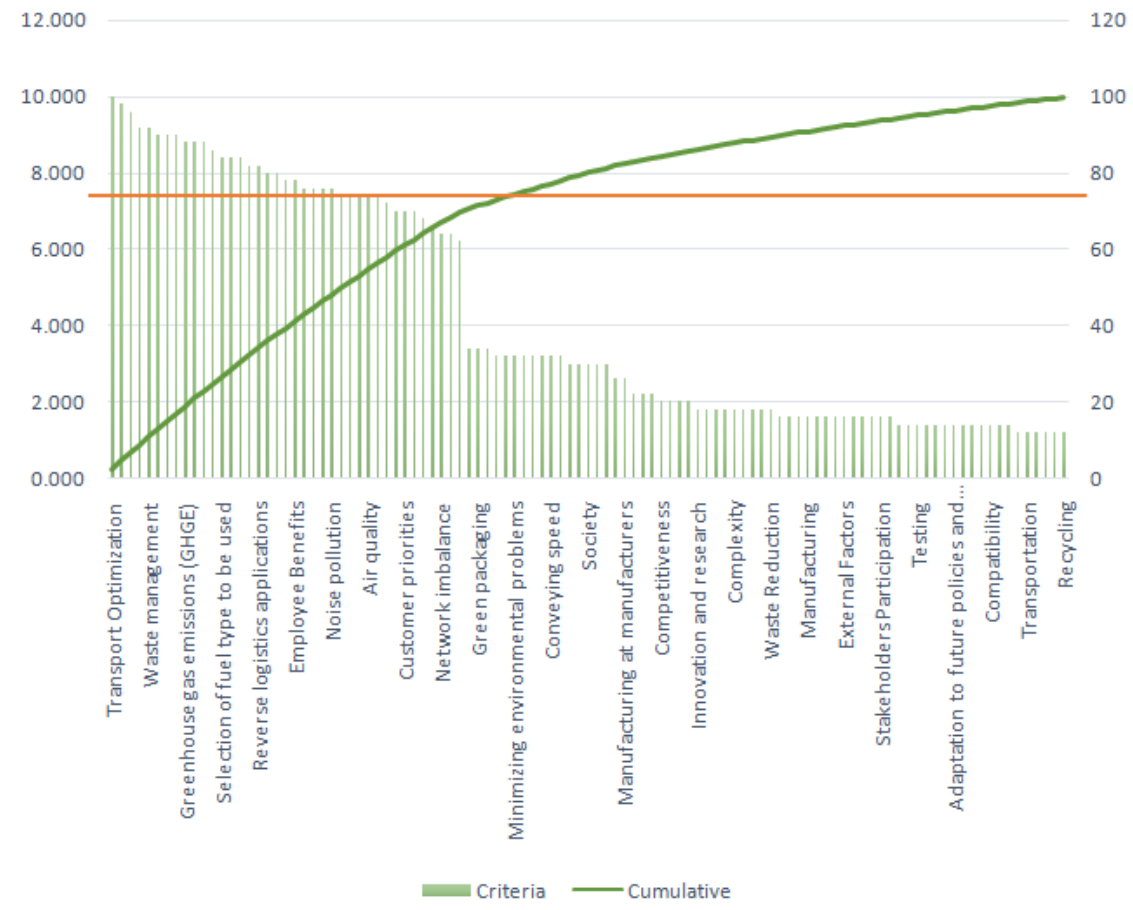

Figure 2

Pareto analysis results

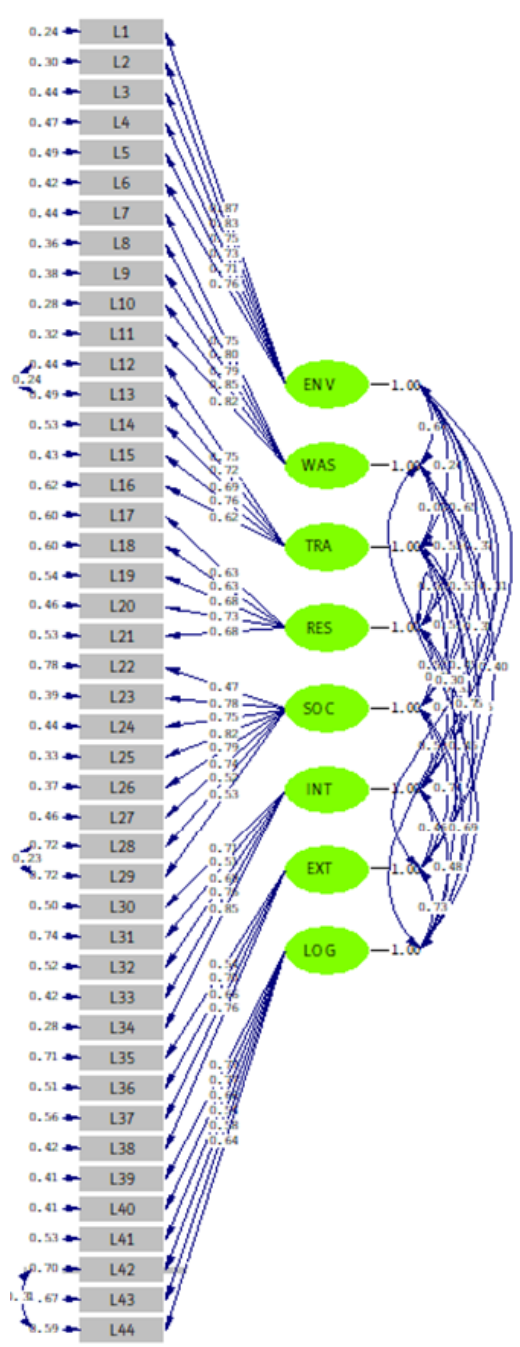

Figure 3 
Confirmatory Factor Analysis modeled according to measurement and latent variables

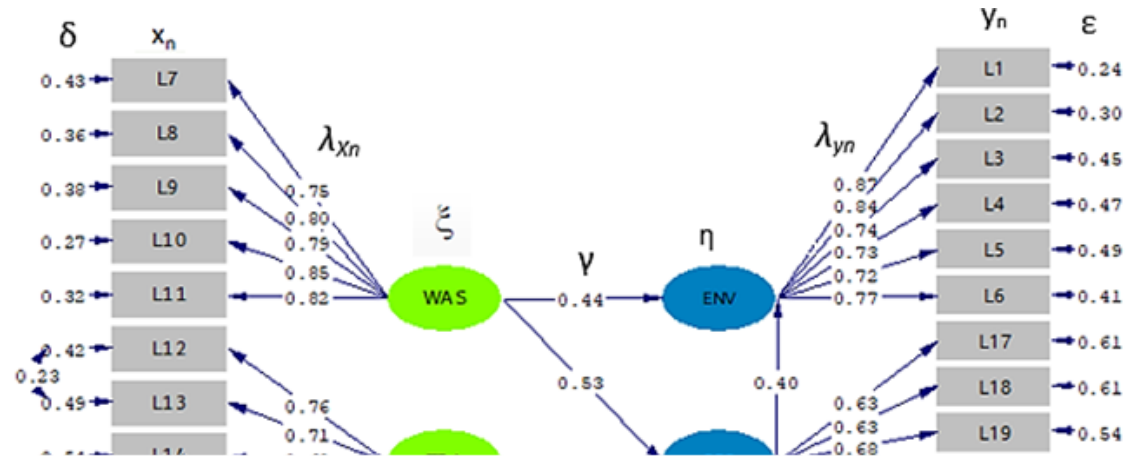

Figure 4

Structural model for sustainable logistics criteria 